\title{
The Dynamics of Language and Exegesis at Qumran
}

\section{Ed. by Devorah Dimant and Reinhard Gregor Kratz}

[Die Dynamik der Exegese und die Sprache in den Schriftrollen vom Toten Meer.]

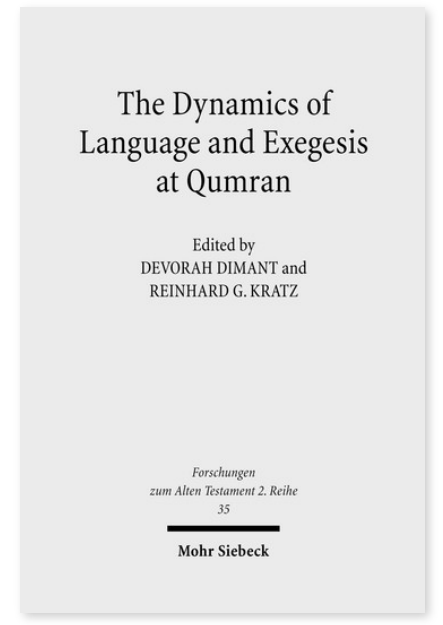

2009. VIII, 226 Seiten. FAT II 35

ISBN 978-3-16-151133-2

DOI 10.1628/978-3-16-151133-2

eBook PDF $64,00 €$

ISBN 978-3-16-149849-7

fadengeheftete Broschur $64,00 €$
Veröffentlicht auf Englisch.

Der Band enthält die Vorträge eines internationalen Symposiums des Centrum Orbis Orientalis (CORO) in Göttingen aus dem Jahr 2007. Die Beiträger beschäftigen sich mit der Sprache und Literatur der Texte vom Toten Meer und konzentrieren sich auf das Phänomen der inner- und außerbiblischen Schriftauslegung. Im Zentrum steht die Frage, wo und auf welche Weise die literarische Produktion biblischer Schriften in die Interpretation und Auslegung dieser Schriften im Rahmen von Paraphrasen (rewritten bible), Kommentaren (Pesharim) und Übersetzungen in andere Sprachen übergeht. Der Band behandelt somit die hermeneutischen Grundlagen, die die Lektüre und Rezeption der Hebräischen Bibel bis heute bestimmen.

\section{Inhaltsübersicht}

\section{Language and Methods}

Moshe Bar Asher: Qumran Hebrew Between Biblical and Mishnaic Hebrew: A Morphological Study - George Brooke: New Perspectives on the Bible and Its Interpretation in the Dead Sea Scrolls - Annette Steudel: Dating Exegetical Texts from Qumran

II. Biblical and Related Writings

Ariel Feldman: The Story of the Flood in 4Q422 - Reinhard G. Kratz: Friend of God, Brother of Sarah, and Father of Isaac: Abraham in the Hebrew Bible and in Qumran - Jan Joosten: The Interpretation of Deuteronomy 29:17-20 in the Hellenistic Period: Septuagint, Qumran and Parabiblical Literature - Devorah Dimant: The Book of Tobit and the Qumran Halakhah Ingo Kottsieper: "Look; son, what Nadab did to Ahikaros...«: The Aramaic Ahiqar Tradition and its Relationship to the Book of Tobit

\section{Sectarian Writings}

Anja Klein: From the 'Right Spirit' to the 'Spirit of Truth': Observations on Ps 51 and 1QS - Liora Goldman: The Exegesis and Structure of Pesharim in the Damascus Document - Peter Porzig: The Ark of the Covenant in the Non-Biblical Texts from Qumran

\section{Devorah Dimant}

Born 1939; studied Religion and Literature of Ancient Judaism; 1974 PhD; Professor emerita for Biblical Studies at the University of Haifa, Israel.

Reinhard Gregor Kratz Born 1957; 1987 Dr. theol., 1990 Habilitation at the University of Zürich; since 1995 Professor for Old Testament/Hebrew Bible at the Theological Faculty of the University Göttingen.

https://orcid.org/0000-0002-4306-1730

\section{Jetzt bestellen:}

https://mohrsiebeck.com/buch/the-dynamics-of-language-and-exegesis-at-qumran-9783161511332?no_cache=1 order@mohrsiebeck.com

Telefon: $+49(0) 7071-923-17$

Telefax: $+49(0) 7071-51104$ 